\title{
Cooperation between The Consumer and Firms as A Determinant of Marketing Innovation: Empirical Study of Portuguese Firms
}

\author{
Jacinta Moreira \\ Polytechnic Institute of Leiria \\ E-Mail: jacinta.moreira@ipleiria.pt \\ Maria José Aguilar Madeira Silva \\ University of Beira Interior \\ E-Mail: msilva@ubi.pt
}

\begin{abstract}
This article analyzes the impact of cooperation with customers and consumers on Portuguese companies' ability to engage in marketing innovation. To this end, the theoretical framework underlying the study comprises the characterization of marketing innovation and cooperation, especially from the companies' standpoint of collaboration with customers and consumers, which will support the formulation of the research hypotheses. The hypotheses are tested using secondary data pertaining to the Community Innovation Survey-CIS 2010; logistic regression models will be applied. According to the results, cooperation with customers and consumers is crucial for marketing innovation to occur in companies as companies that cooperate with others show a greater propensity to innovate in marketing.
\end{abstract}

Keywords: Marketing Innovation, Cooperation, Consumer, CIS 2010

\section{INTRODUCTION}

Today's companies find an important source of collaboration in the market for developing their internal activities, especially those concerning innovation. It is possible to establish cooperative relationships with most, if not all, stakeholders. Thus, it is common for companies to seek ideas regarding their suppliers, competitors, customers and consumers, among others, that enable their participation in the development of the product resulting from innovative activity, thereby converting innovation to an open concept. 
This becomes even more significant when the marketing innovation is the dominant sphere. In this case, the participation of other external entities, especially customers and consumers, becomes a determining factor in developing successful innovation in terms of product as well as price, promotion, and distribution.

As a result, this study aims to examine the influence of cooperation with customers and consumers in firms' marketing innovation capacity, focusing the analysis on the study of Portuguese industrial and service firms. The innovative capacity of corporate marketing is herewith understood as innovation occurring in any of the Ps of the marketing mix.

In order to meet the goal of the study, two theoretical hypotheses are formulated, which are duly supported by the literature review. These hypotheses are empirically tested using the logistic regression models. For this purpose, secondary data retrieved from the Community Innovation Survey-CIS 2010 are used.

An outline of the structure of the work is provided here. In section two, based on the relevant literature about marketing innovation and cooperation, the hypotheses used to empirically test the statistical model are formulated. Section three defines the sample, characterizes the variables used in the empirical study, and presents the logistic regression models. Section four presents the results attained and carries out the respective analysis in terms of the influence of cooperation on the part of customers and consumers in the innovative marketing ability of Portuguese companies. The final section puts forward the conclusions.

\section{LITERATURE REVIEW}

Innovation is one of the most important aspects of current business studies, providing an essential basis for understanding the evolution of the global economy. Moreover, marketing plays a key role in the understanding and management of innovation through the development of new products and services or by making changes to existing ones in order to provide an effective response to market needs.

Marketing innovation is the implementation of a new concept or new marketing strategy, different from the existing marketing methods and from the one used in the company, that considers changes at different levels-namely: (i) the product or service in terms of the design or packaging; (ii) the distribution, inclusive of new methods of distribution or placement of products and services or new sales channels; (iii) the promotion, using new techniques or media; or (iv) pricing policy. These changes aim to increase the penetration of the products and services of the company in the current market or new markets(Ray\&Knight,1994; Heunks, 1998; Shergill \& Nargundkar, 2005). 
In this regard, Harms, Rohmann, Heinrich, Druener, and Trommsdorff (2002) consider that innovation, as a new element of the marketing mix, will promote new and obvious advantages for companies. According to Chou(2009) and Cherchem (2012), innovation is the central element of differentiation and superior performance because it allows companies to release new products and services, develop new methods and production processes, and gain organizational access to new markets or use a new source of raw material.

However, for a long time, innovation was conceived as only an internal process and, therefore, with a very limited use of external knowledge(Clark \& Wheelwright, 1993; Dodgson, Gann, \&Salter, 2006) . Today, in contrast, the principles of marketing innovation postulate that the focus should be on the company's external resources, market opportunities, consumers, technology, competitors, and changes in the structure and values of society, among other factors (Cherchem, 2012; Chang \& His, 2010; Gong \& Jiing-Lih , 2010).

Thus, it can be stated that innovations are the basis for the success of companies and for the market, although — according to Heunks (1998) and O'Connor (2006) ] this depends to a large extent on the cooperation with external partners, particularly with consumers and customers, suppliers, competitors, public and private R\&D institutions, and universities and other higher education institutions. In order to confirm this assumption, Katila and Ahuja (2002) reported that the use of external knowledge is positively related to successful innovation. Furthermore, according to Chou (2009), the greatest innovations can result in competitive advantages and superior financial returns for companies.

Following this theme, marketing innovation can be very important in markets' future development; however, for this to occur, companies have to comply with two essential requirements: having direct contact with the consumer or customer and positioning oriented in relation to the competition. Regarding the first aspect, consumers and customers are the pivotal elements during the release of the new product or service, contributing mainly to the reduction of the risk of failure of the new product on the market, so that the satisfaction condition demonstrates a priori conditions during the strategic planning throughout the company. As a result, the innovative idea should soon result in continuous customer satisfaction and a positive company image (Harms et al., 2002; Gassmann \& Enkel, 2004). Regarding the positioning, image of the product \& company in the consumer's mind, which must be constantly reinforced because it contributes directly to the market differentiation and can be expanded to other markets (Harms et al., 2002). 
Yet in order to attain the aforementioned success, it is also necessary to apply the tools of marketing innovation to reality, particularly with regard to communication and cooperation. Currently, much of the stimulus for innovation arises from informal communications among employees of the company or even between them and customers and consumers; thus, cooperation is also essential and must occur among all actors involved in innovation, with an added advantage insofar as such an act facilitates the acceptance of innovation by the market (Harms et al., 2002; O'Connor, 2006).

Cooperation between the company and the different partners can be defined as their active participation in the company's innovation projects, together with other individuals, companies, or institutions, where at least one partner withdraws commercial counterparts (Community Innovation Survey, 2010; O'Connor, 2006). According to the definition of cooperation presented, it is essential that the company develop an active network or an established innovation system (Edquist, 1997 ; Romijn \& Albaladejo, 2002); however, in order for this to succeed, bonds of trust must be established between the partners and the negative effects associated with innovation minimized, particularly the associated risk (Fritsch \& Lukas, 1999 ; Fritsch \& Lukas, 2001 ; Kaufmann \& Tödtling, 2001). As pointed out by Padmore, Schuetze, \& Gibson (1998), external collaboration helps overcome companies' limitations with respect to their own resources and capabilities to develop new products and potential innovations.

Among all the possible innovation partners, customers and consumers are those who require the most attention as they are the source of the first process inputs; information about their current potential needs and desires is, therefore, the most important source of innovation for companies (Cherchem, 2012; Padmore et al., 1998; Hodock, 1979 ; Von Hippel, 2005 ; Poetz \& Schreier, 2012). As referred to by Von Hippel (1998), Lundvall (1992), and Enkel, Gassmann, \& Chesbrough (2009), when the company knows what its customers and consumers need, it has advantages over its competitors because, on the one hand, it might be able to meet those needs more rapidly and, on the other hand, it experiences reduced risk associated with the uncertainty of the introduction of new products into the market. Moreover, according to Padmore et al.(1979), customers and consumers can be an important channel of information about the innovations of competitors.

Shaw (1994)recognizes some advantages to adjacent relationships between companies and customers, including: (i) acquisition of complementary knowledge, predominantly according to the user's perspective; (ii) knowledge of consumer behavior as a predictor of the outcome of innovation; (iii) setting of the innovation 
introduced to the market profile; and (iv) identification of changes in consumer opinion. Concerning the objectives of cooperation between companies and customers, Chesbrough and Schwartz (2007)consider that it (i) increases the profitability of the company, (ii) increases innovative capacity, and (iii) creates greater flexibility in R\&D.

In addition, Etgar (2008)identified some social benefits to the consumer resulting from the process of collaboration, particularly in terms of improving social status, because the consumer gains recognition by others as a source of valuable information as well as the enlargement of a network of contacts as a result of an active participation in communities of individuals who share the same interests.

Ultimately, the process of cooperation and collaboration in innovation between companies and customers is also a unique, memorable, and extremely important experience for the latter insofar as it allows the creation of value not only for the customer and the company, but also for other customers and consumers, in addition to enabling customer participation throughout the innovation process and increasing the client's learning process (Von Hippel, 2005 ; Grissemann \& Stokburger-Sauer, 2012).

Therefore, clients can be considered partial employees of the company, investing in it their time, money, and technical and psychological efforts as they are responsible for the outcome of the innovation process and develop, as a result, a whole range of positive affective reactions about the product or service (Grissemann \& StokburgerSauer, 2012 ; Xie, Bagozzi, \& Troye, 2008 ; Hoyer, Chandy, Dorotic, Krafft, \& Singh, 2010). According to Homburg and Gierin (2001), when consumers have the opportunity to collaborate in the production of a good, they are more likely to repeatedly buy from the same company and recommend the company to others; thus, consumer satisfaction resulting from the described process is also positively related to customer loyalty.

Given the above, it is easy to recognize the increased importance that customers and consumers have in external relationships established in the context of innovation activities. According to Lettl, Herstatt, \& Gemuenden (2006) and Van der Meer (2007), these activities assume a more intensive, collaborative attitude in the early stages of the development of the concept or idea, leading customers and consumers to propose goods that best suit their needs. Dodgson et al. (2006)explained that this results in the disruption of the traditional view of the consumer, perceived as being useful only in market research and product testing. Thus, the consumer assumes a more active role in innovation activities. In this regard, some recent studies have shown that collaborative innovation is already a common practice, particularly in the biotechnology industry (Powell, 1998), computer and electronic product industries 
(Lakhani \& Von Hippel, 2003; Bagozzi \& Dholakia, 2006; Dittrich \& Duysters, 2007; Fuchs \& Schreier, 2011), and even the car industry (Ili, Albers, \& Miller, 2010 ; Wilhelm, 2011 ; Bueno \& Balestrin, 2012).

However, the participation of customers and consumers in the innovation process can be considered both internally and at the national level as well as at the foreign or international level. According to DeBresson, Hu, Drejer, \& Lundvall (1998), collaborations at the international level are the dominant character of this participation.

In summary, firms are increasingly showing the ability to adopt new technologies and new ideas developed by other individuals and organizations; they are thus able to appropriate some of the returns derived therefrom, thereby enabling the increase of investment in new knowledge produced externally through cooperation and collaboration among different actors (Kaufmann \& Tödtling, 2001). As such, innovation marketing should not be understood as an isolated act or the product of a single actor. Rather, the result is a network of joint work and a dynamic learning process and conference providing the interaction between the company and a whole range of stakeholders, including company consumers and customers (Phong-inwong \& Ussahawanitchakit, 2011 ; Kaufmann\& Tödtling, 2001 ; Padmore et al., 1998 ; Von Hippel, 2003 ; Lundvall, 2006 )Based on the literature reviewed, it is pertinent to analyze the influence of cooperation between customers/consumers and companies in the innovative capacity of marketing. Hence, the following hypotheses are formulated:

Hypothesis 1: Cooperation between customers/consumers and businesses positively influences marketing innovation.

Hypothesis 2: Companies that cooperate with customers and consumers show a greater propensity to innovate in marketing than companies that cooperate with other partners.

\section{METHODOLOGY}

The purpose of this section is to characterize the sample used in the study and the methodology inherent in collecting the data, as well as describe the variables used, including the dependent variable of marketing innovation and the independent variables related to cooperation. Finally, it will present the data analysis model.

\section{Sample and Data Collection}

The data used in this study were gleaned from the Community Innovation Survey-CIS 2010, whose application in Portugal took place between July 2011 and April 2012 for the period of analysis from 2008 to 2010. Data were collected through 
an electronic platform, having been subjected to the same validation by the General Directorate of Statistics of Education and Science/Ministry of Education and Science (GDSES/MES).

The population on which the analysis focuses includes all Portuguese manufacturing and service companies with at least 10 workers, established in the Portuguese territory, and representing companies from Sections B, C, D, E, F, G, H, J, K, M, and Q of CAE-Rev. 3 (Table 1) (GDSES, 2012).

Table 1 Areas of Activity of the Sample Companies

\begin{tabular}{cl}
\hline Section & \multicolumn{1}{c}{ Activity } \\
\hline $\mathrm{B}$ & Extractive industries \\
$\mathrm{C}$ & Manufacturing \\
$\mathrm{D}$ & Companies of electricity, gas, steam, water and cold \\
$\mathrm{E}$ & Companies purification and distribution of water, sanitation, waste \\
& management and remediation activities \\
$\mathrm{F}$ & Construction \\
$\mathrm{G}$ & Trade; Repair of motor vehicles and motorcycles \\
$\mathrm{H}$ & Transport and storage \\
$\mathrm{J}$ & Information and communication activities \\
$\mathrm{K}$ & Financial and insurance activities \\
$\mathrm{M}$ & Consulting activities, scientific and technical activities \\
$\mathrm{Q}$ & Human health activities and social support \\
\hline
\end{tabular}

Source: GDSES (2012)

The sample, comprising 6,160 companies, was designed by -the National Institute of Statistics (INE) based on guidelines and recommendations established by EUROSTAT, the statistical office of the European communities.

\section{Characterization of Variables}

For this study, we used data with underlying indicators related to innovation activities developed by Portuguese companies, including activities related to marketing innovation, and data relating to cooperation under these activities with different partners.

Bearing the purpose of the study in mind, we considered Portuguese companies with innovative marketing during the 2008-2010 period if they introduced some innovation related to: (i) significant changes in appearance/aesthetic or packaging of products (goods and/or services); (ii) new techniques or means of communication for the promotion of goods or services; (iii) new methods of distribution/placement of products (goods and/or services) or new sales channels; or (iv) new pricing policies for products. 
The innovative marketing capacity corresponds to the dependent variable, taking the value 1 if the company innovated and 0 otherwise (i.e., if there was no innovation).

The independent variables are represented by two variables considered at the level of cooperation: (i) cooperation with customers and consumers and (ii) cooperation with other partners, comprised of other group companies, suppliers, competitors, consultants, laboratories or private institutions of $\mathrm{R} \& \mathrm{D}$, universities or other higher education institutions, and laboratories of the state or other public organizations carrying out R\&D activities.

Table 2 summarizes the dependent and independent variables:

Table 2 Dependent and Independent Variables

\begin{tabular}{|c|c|c|}
\hline Dependent Variable & Independent Variables & Value \\
\hline \multirow{2}{*}{$\begin{array}{c}\text { Innovative } \\
\text { Marketing Capacity } \\
\text { (INOV_MK) }\end{array}$} & $\begin{array}{c}\text { Cooperation with customers and } \\
\text { consumers }\left(\mathrm{CO} \_\mathrm{cc}\right)\end{array}$ & $\begin{array}{l}1=\text { company cooperated during } \\
\text { the activity of marketing } \\
\text { innovation } \\
0 \text { = company has not } \\
\text { cooperated during the activity } \\
\text { of marketing innovation }\end{array}$ \\
\hline & $\begin{array}{l}\text { Cooperation with other partners } \\
\text { (CO_op) }\end{array}$ & $\begin{array}{l}1=\text { company cooperated during } \\
\text { the activity of marketing } \\
\text { innovation } \\
0 \text { = company has not } \\
\text { cooperated during the activity } \\
\text { of marketing innovation }\end{array}$ \\
\hline
\end{tabular}

\section{Method: Logistic Regression Model}

Based on the literature reviewed, marketing's innovative capacity is a complex phenomenon influenced by a wide range of factors, including the company's cooperation with external partners. Faced with the need to explore these relationships, we chose to use the logistic regression model, which has also been widely used in the empirical studies analyzed (Kaufmann \& Tödtling, 2001 ; Masso \& Vahter, 2008 ; Heidenreich, 2009). This provided an analytical technique suited for the analysis as it includes a categorical dependent variable and one or various independent variables, as presented below:

Model 1: INOV_Mk $=\beta_{0}+\beta_{1} C O \_C C+\varepsilon_{i}$

where: INOV_Mk $=$ Marketing Innovation; $\varepsilon_{i}=$ Residue; $\beta=$ Coefficients; $\mathrm{CO}_{-} \mathrm{CC}=$ cooperation with consumers and customers. 
Model 2: INOV_Mk $=\beta_{0}+\beta_{1 a} C O \_c c_{n}+\beta_{1 b} C O \_c c_{i}+\beta_{1 c} C O \_o p_{n}+\beta_{1 d} C O \_o p_{i}+\varepsilon_{i}$

where: INOV_Mk $=$ Marketing Innovation; $\varepsilon_{\mathrm{i}}=$ Residue; $\beta=$ Coefficients; $\mathrm{CO}_{-} \mathrm{cc}_{\mathrm{n}}=$ cooperation with national consumers and customers; $\mathrm{CO} \mathrm{cc}_{\mathrm{i}}=$ cooperation with international consumers and customers; $\mathrm{CO} \_\mathrm{op}_{\mathrm{n}}=$ cooperation with other national partners e CO_op $\mathrm{i}_{\mathrm{i}}=$ cooperation with other international partners.

\section{RESULTS AND DISCUSSION}

This section studies the logistic regression models to determine the influence of cooperation with customers in the marketing innovative capacity of Portuguese companies. The literature review led to the assumption that a relationship exists between marketing innovation in companies and collaboration with customers and consumers; therefore, the application of logistic regression models to the data from the Community Innovation Survey is pertinent, allowing for the study of the behavior of the variables in question.

Consequently, we defined the first hypothesis, which posits the following:

H1: Cooperation between customer/consumers and businesses positively influences innovation marketing.

In order to empirically test the hypothesis stated, a simple logistic regression model was elaborated, given the presence of a dependent variable (marketing innovation) and an independent variable (cooperation with customers and consumers), which were both dichotomous, as shown in Table 3.

According to the model results, and analyzing first the relationship between the two variables, a positive linear relationship — albeit an extremely weak one-does indeed exist between cooperation with customers and consumers and marketing innovation developed by firms, which is explained by the correlation coefficient having a value of 0.069 . This indicator suggests that marketing innovation differs on average by $6.9 \%$ from cooperation with customers and consumers.

In the same line of analysis, the coefficient of determination, which reflects the proportion of variance explained by the model, has a value of 0.005 . In other words, only $0.5 \%$ of innovation in marketing occurring in the companies studied is explained by cooperation with customers and consumers, which confirms the explanation of the previous value (i.e., the existence of a weak relationship between the independent and dependent variables). 
Table 3 Logistic Regression Model of Cooperation with Customers and Consumers and Marketing Innovation

\begin{tabular}{cccc}
\hline Model & $\mathbf{R}$ & $\mathbf{R}^{\mathbf{2}}$ & $\begin{array}{c}\text { Standard deviation of } \\
\text { the estimate }\end{array}$ \\
\hline 1 & 0.069 & 0.005 & 0.47515 \\
\hline
\end{tabular}

a. Predictors: (Constant), $\mathrm{CO}_{-} \mathrm{CC}$

b. Dependent variable: INOV_Mk

\begin{tabular}{ccccccc} 
ANOVA & \multicolumn{1}{c}{ Sum of } \\
Model & & $\begin{array}{c}\text { Degrees of } \\
\text { squares }\end{array}$ & $\begin{array}{c}\text { Mean } \\
\text { square }\end{array}$ & F & Sig. \\
\hline 1 & Regression & 1.096 & 1 & 1.096 & 4.853 & 0.028 \\
& Residue & 230.286 & 1020 & 0.226 & & \\
& Total & 231.382 & 1021 & & & \\
\hline
\end{tabular}

a. Predictors: (Constant), CO_CC

b. Dependente variable: INOV_Mk

\section{Coefficients}

\begin{tabular}{cccccc}
\hline Model & & $\begin{array}{c}\text { Standard } \\
\text { error }\end{array}$ & Beta & t & Sig. \\
\hline 1 & (Constant) & 0.023 & & 26.605 & 0.000 \\
& CO_CC & 0.30 & 0.69 & 2.203 & 0.028 \\
\hline
\end{tabular}

Dependente variable: INOV_Mk

Given that the parameters of the straight line obtained in the model have a constant value of 0.615 and that the value of the independent variable cooperation with customers and consumers is 0.066 , it can be said that, due to the positive correlation, higher cooperation with customers and consumers means that it is more likely that the company innovates in marketing.

Finally, considering the significance of the model, we obtained a value of 0.028 ; this is lower than the reference value of 0.05 (significance level 5\%), thereby confirming hypothesis 1 . The same is confirmed by the Student $t$ test, according to which a value of $F$ ranging from $4.853 \%$ to $5 \%$ should lead to a $t$-value greater than 1.645. As the value of $t$ obtained for the regression is 2.203, which is superior to the tabulated value, it confirms the hypothesis in question-namely, cooperation with customers and consumers positively influences the company's ability to innovate in marketing.

In summary, the logistic regression model is valid: A company's cooperation with customers and consumers is a determinant of marketing innovation. However, it is a model without statistical consistency as, given the values of the coefficients, the independent variable (a single variable) has a very weak explanatory power. In this 
regard, and in order to improve the statistical model, it is necessary to introduce new independent variables. In this sense, the study of the behavior of the variable cooperation among clients and customers and other partners, at both the national and international levels, in marketing innovation is provided below.

As suggested by the literature reviewed, in the context of their marketing innovation activities, companies can cooperate with a wide range of national and international partners in addition to customers and consumers, including other group companies, suppliers, competitors, consultants, laboratories or private R\&D institutions, universities or other higher education institutions, and laboratories of the state or other public organizations engaged in R\&D activities. However, according to most studies analyzed, the set of partners are, in fact, customers and consumers who represent the largest and most important source of ideas for innovation that occurs in companies. Thus, we defined the second hypothesis (H2) as follows: "Companies that cooperate with customers and consumers show a greater propensity to innovate in marketing than companies that cooperate with other partners."

In order to empirically test the hypothesis, a logistic regression model was elaborated, considering the cooperation partners at two levels: a) customers and consumers and $b$ ) other partners (adding to the latter all other partners set out under cooperation). In addition, the geographic location (national or international) was also considered as this was mentioned by the work as being preponderant. Table 4 presents the results of the logistic regression.

As indicated by Table 4 and the analysis of the first obtained model (Model A), the use of the Wald test statistic is a variable that is not statistically significant at 5\% (cooperation with international customers and consumers). This implies the execution of a new model (Model B), in which the variable is deleted. In Model B, the independent variables are statistically significant at 5\%. Moreover, the quality of fit has not found significant changes for the previous model, which is confirmed through the parameters presented - namely, the predicative capacity (96\%) resulting from the comparison between the values of the dependent variable predicted by the model and the observed values; statistic chi-square (20.560), with a value of evidence associated with 0.000; and the value of the log-likelihood (1298.181). Therefore, we can proceed with the analysis of estimates of the final model and with the testing of the associated hypothesis. 
Table 4 Logistic Regression Model of Influence of Cooperation in Marketing Innovation

\begin{tabular}{|c|c|c|c|c|c|c|c|}
\hline \multirow[b]{2}{*}{ Modelo2 } & \multicolumn{2}{|c|}{ Model A } & \multicolumn{5}{|c|}{ Model B } \\
\hline & $\begin{array}{l}\text { Estimate of } \\
\text { coefficients }\end{array}$ & $\begin{array}{c}\text { Test } \\
\text { value }\end{array}$ & $\begin{array}{l}\text { Estimate of } \\
\text { coefficients }\end{array}$ & $\begin{array}{l}\text { Stand. } \\
\text { Dev. }\end{array}$ & Wald & $\begin{array}{c}\text { Test } \\
\text { value }\end{array}$ & $\begin{array}{l}\text { Exp } \\
\text { (B) }\end{array}$ \\
\hline Cooperation: & & & & & & & \\
\hline $\begin{array}{l}\text { National customers and } \\
\text { consumers }\end{array}$ & 0.311 & 0.026 & 0.303 & 0.136 & 4.943 & 0.026 & 1.354 \\
\hline $\begin{array}{l}\text { International customers } \\
\text { and consumers }\end{array}$ & -0.040 & 0.810 & & & & & \\
\hline Otheir national partners & 0.444 & 0.021 & 0.442 & 0.192 & 5.322 & 0.021 & 1.557 \\
\hline International partners & 0.324 & 0.023 & 0.313 & 0.135 & 5.385 & 0.020 & 1.367 \\
\hline Constant & -0.048 & 0.797 & -0.048 & 0.185 & 0.067 & 0.795 & 0.953 \\
\hline $\begin{array}{c}\text { Quality of model adjustment } \\
\text { Correctly predicted (\%) }\end{array}$ & 96.0 & & 96.0 & & & & \\
\hline Chi square & 20.618 & 0.000 & 20.560 & & & 0.000 & \\
\hline Log likelihood & 1298.123 & & 1298.181 & & & & \\
\hline Number of cases & 1022 & & 1022 & & & & \\
\hline
\end{tabular}

Hypothesis H2 relates to the company's ability to innovate in marketing and its cooperation with customers and consumers or other partners. The literature showed that companies that cooperate with customers and consumers are more likely to develop innovations(Powell, 1998; Lakhani \& Von Hippel, 2003 ; Bagozzi \& Dholakia, 2006 ; Dittrich \& Duysters, 2007 ; Fuchs \& Schreier, 2011 ; Ili et al., 2010 ; Wilhelm, 2011 ; Bueno \& Balestrin, 2012). According to DeBresson et al. (1998), this assumes greater weight if customers and consumers have an international scope.

Based on the model's results, despite the fact that cooperation with national customers and consumers is predominant in marketing innovation, it is not possible to confirm the assumption of Hypothesis 2 as other partners play a more decisive role, taking into account the marginal effects associated with the variables.

In this connection, cooperation with customers and consumers is positively related to the firm's ability to innovate in marketing, as evidenced by the value of the point estimate associated with the variable (0.303). Similarly, companies that engage in this type of cooperation have an advantage (1.354) in developing innovation activities within their marketing. However, it appears that companies that cooperate with other partners-whether suppliers, competitors, public or private R\&D institutions and universities, or others - show an advantage in marketing innovation greater than that indicated. Thus, companies that cooperate with other national and international partners are also empowered to innovate in marketing, as evidenced by the value of the point estimate associated with the variables $(0.442$ and 0.313 , 
respectively). However, they demonstrate a superior advantage with regard to the practice of innovative activities in marketing as the value of the marginal effects associated with the two variables is 1.557 in the case of cooperation with other national partners and 1.367 for cooperation with other international partners. This is a higher advantage than either of these two cases.

In summary, cooperation with customers has been shown to be crucial in marketing innovation (Model 1), although cooperation with other partners is more advantageous for companies that have developed innovative practices (Model 2).

\section{CONCLUSIONS}

This study sought to analyze the influence of cooperation with customers and consumers in the innovative marketing capacity of Portuguese companies. To this end, data were gathered from the Community Innovation Survey-CIS 2010 and analyzed, taking into account the line of research suggested by several studies considered in the literature review.

According to the literature reviewed, a whole set of cooperation partners exists outside the firm and appear to facilitate innovation marketing. These partners include suppliers, other group companies, customers and consumers, competitors, the public and private R\&D institutions, as well as universities and other higher education institutions. However, customers and consumers stand out in this set. The research reviewed demonstrates that they constitute the largest and most important source of ideas for companies wishing to develop innovations, especially from a marketing perspective.

Based on this assumption, two hypotheses were formulated and empirically tested using logistic regression models. The model results indicate that, on the one hand, cooperation with customers and consumers is a determining factor of the marketing innovation occurring in firms; on the other hand, firms that cooperate with such partners, including national ones, are more likely to innovate in marketing, although the resulting benefit is greater when companies use other types of cooperation partners. The results suggest that such practices have significant, positive effects on innovation in marketing. Thus, higher cooperation with national customers and consumers, or other types of national or international partners, means that firms have a higher propensity to innovate in marketing.

From the study results, a few considerations are derived that can be understood in the form of contributions, limitations of the study, and suggestions for future research. The main contribution of this work consisted of the study of marketing innovation, which has been infrequently explored in the literature, largely due to the fact that it is 
a phenomenon of recent interest. Another contribution is the analysis of cooperation with Portuguese companies' external partners as a determining factor of the innovative capacity of marketing.

The limitations observed during the study arise mainly from not having carried out a detailed analysis of all of the partners with which firms have established cooperation in innovation activities of marketing in order to verify the biggest advantages that show innovation. Another limitation stemmed from not having analyzed the impact of cooperation on each of the components of marketing innovation - namely, product, price, promotion, and distribution. Using secondary data (i.e., CIS 2010) resulted in a third limitation: limited access at the database level. Although access to the data was provided starting in May 2013, these figures relate to the 2008-2010 period, so the data's contextualization might slightly offset the current economic climate.

Finally, with regard to suggestions for future research and also taking into account the limitations highlighted, future research should explore the achievements of the various levels of cooperation partners in marketing innovation and the analysis of the impact of cooperation on clients, customers, or possibly other partners in each of the strands of innovation in marketing. In order to obtain a comparative basis, the execution of an empirical study using data from other European countries in which the Community Innovation Survey was administered could be beneficial.

\section{REFERENCES}

Bagozzi, R., \& Dholakia, U. (2006). Open source software user communities : A study of participation in Linux user groups. Management Science, 52(7), 10991115. http://dx.doi.org/10.1287/mnsc.1060.0545

Bueno, B., \& Balestrin, A. (2012). Collaborative innovation : an open approach in the development of new products. $R A E, 52(5), 517-530$.

Chang, S., \& His, L. (2010). Social capital, creativity and new product advantage : an empirical study. International Journal of Electronic Business Management, 8, 43-55.

Cherchem, M. (2012). The Impact of the Imitation and Innovation Marketing in Services: the case of the Banks and Insurance. Technology and Investment, 3, 5762. http://dx.doi.org/10.4236/ti.2012.32008

Chesbrough, H., \& Schwarts, K. (2007). Innovating business models with codevelopment partnerships. Research Technology Management, January-February, 55-59. 
Chou, H. (2009). The effect of market orientation intention and superiority on new product performance. The Journal of American Academy of Business, 14(2), 9397.

Community Innovation Survey (2010). Planning, Strategy, Evaluation and International Relations Ministry of Science, Technology and Higher Education, Lisbon, Portugal.

Clark, K., \& Wheelwright, S. (1993). Managing new product and process development, New York: The Free Press.

DeBresson, C., Hu, X., Drejer, I., \& Lundvall, B. (1998). Innovative activity in the learning economy: a comparison of systems in 10 OECD countries. Paris, OECD.

Dittrich, K., \& Duysters, G. (2007). Networking as a means to strategy change: the case of open innovation in mobile telephony. Journal of Product Innovation Management, 24, 510-521. http://dx.doi.org/10.1111/j.1540-5885.2007.00268.x

Dodgson, M., Gann, D., \& Salter, A., (2006). The role of technology in the shift towards open innovation: the case of Procter \& Gamble. $R \& D$ Management, 36(3), 333-346. http://dx.doi.org/10.1111/j.1467-9310.2006.00429.x

Edquist, C. (1997). Systems of innovation approaches - their emergence and characteristics. In: Edquist, C. (Ed.), Systems of Innovation: Technologies, Institutions and Organizations, Chapter I, London, Printer, 1-35.

Enkel, E., Gassmann, O., \& Chesbrough, H. (2009). Open R\&D and open innovation: exploring the phenomenon. R\&D Management, 39(4), 311-316. http://dx.doi.org/10.1111/j.1467-9310.2009.00570.x

Etgar, M. (2008). A descriptive model of the consumer co-production process. Journal of the Academy of Marketing Science, 36(1), 97-108. http://dx.doi.org/10.1007/s11747-007-0061-1

Fritsch, M., \& Lukas, R. (1999). Innovation, cooperation and the region. In: Audretsch, D., \& Thurik, R. (Eds.), Innovation, Industry Evolution and Employment, Cambridge University Press, Cambridge, 157-181.

Fritsch, M., \& Lukas, R. (2001). Co-operation in regional innovation systems. Regional Studies, 35(4), 297-307. http://dx.doi.org/10.1080/00343400120046995

Fuchs, C., \& Schreier, M. (2011). Customer empowerment in new product development. Journal of Product Innovation Management, 28(1), 17-32. http://dx.doi.org/10.1111/j.1540-5885.2010.00778.x

Gassmann, O., \& Enkel, E. (2004). Towards a theory of open innovation: three care process archetypes. $R \& D$ Management Conference (RADMA), Lisbon, Portugal. 
GDSES, (2012). Statistical summaries| CIS 2010 - Community Innovation Survey 2010. General Directorate of Statistics of Education and Science, Lisbon, Portugal.

Gong, J., \& Jiing-Lih, F. (2010). Employee Learning Orientation, Transformational Leadership, and Employee Creativity: The Creativity Self-efficacy. Academy of Management Journal, 54(4), 765-778.

Grissemann, U., \& Stokburger-Sauer, N. (2012). Customer co-creation of travel services: the role of company support and customer satisfaction with the cocreation performance. Tourism Management, 33, 1483-1492. http://dx.doi.org/10.1016/j.tourman.2012.02.002

Harms, F., Rohmann, S., Heinrich, M., Druener, M., \& Trommsdorff, V. (2002). Innovative marketing. Pharmaceuticals Policy and Laws, 5, 135-149.

Heidenreich, M. (2009). Innovation patterns and location of European low - and medium - technology, Research Policy, 38, 483-494. http://dx.doi.org/10.1016/j.respol.2008.10.005

Heunks, F. (1998). Innovation, creativity and success. Small Business Economics, 10, 263-272.

Hodock, C. (1979). Stratégies behind the winers and losers. Journal of Business Stratégy, 3, 38.

Homburg, C., \& Giering, A. (2001). Personal characteristics as moderators of the relationship between customer satisfaction and loyalty - an empirical analysis. Psychology and Marketing, 18(1), 43-66. http://dx.doi.org/10.1002/15206793(200101)18:1\%3C43::AID-MAR3\%3E3.0.CO;2-I

Hoyer, W., Chandy, R., Dorotic, M., Krafft, M., \& Singh, S. (2010). Consumer cocreation in new product development. Journal of Service Research, 13(3), 283296. http://dx.doi.org/10.1177/1094670510375604

Ili, S., Albers, A., \& Miller, S. (2010). Open innovation in the automotive industry. R\&D Management, $40 \quad$ (3), 246-255. http://dx.doi.org/10.1111/j.14679310.2010.00595.x

Katila, R., \& Ahuja, G. (2002). Something old, something new: A longitudinal study of search behaviour and new product introduction. Academy of Management Journal, 45(6), 1183-1194. http://dx.doi.org/10.2307/3069433

Kaufmann, A., \& Tödtling, F., (2001). Science-industry interaction in the process of innovation: the importance of boundary-crossing between systems. Research Policy, 30, 791-804. http://dx.doi.org/10.1016/S0048-7333(00)00118-9

Lakhani, K., \& Von Hippel, E. (2003). How open source software works: "Free" userto-user assistance. Research Policy, 32(6), 923-943. 
Lettl, C., Herstatt, C., \& Gemuenden, H. (2006). User's contributions to radical innovation: evidence from four cases in the field of medical equipment technology. R\&D Management, 36(3), 251-272.

Lundvall, B. (1992). Introduction. In : Lundvall, B. (Ed.). National Systems of Innovation: Towards a Theory of Innovation and Interactive Learning, Chapter II, Printer, London, 1-19.

Masso, J., \& Vahter, P. (2008). Technological innovation and productivity in latetransition Estonia: econometric evidence from innovation surveys, The European Journal of Development Research, 20(2), 240-26.1. http://dx.doi.org/10.2139/ssrn.1126281

O’Connor, G. (2006). Open, Radical Innovation: Toward an Integrated Model in Large Established Firms. In: Chesbrough, H., Vanhaverbeke, W., \& West, J. (Eds.), Open Innovation: Researching a New Paradigm, Oxford University Press.

Padmore, T., Schuetze, H., \& Gibson, H. (1998). Modeling systems of innovation: an enterprise - centered view. Research Policy, 26, 605-624. http://dx.doi.org/10.1016/S0048-7333(97)00039-5

Phong-inwong, R., \& Ussahawanitchakit, P. (2011). Creativity, Marketing Innovation and Marketing Success: Evidence from Home Decoration Export Businesses in Thailand. International Journal of Business Research, 11(4), 89-103.

Poetz, M., \& Schreier, M. (2012). The Value of Crowdsourcing: Can Users Really Compete with Professionals in Generating New Product Ideas?. Journal Of Product Innovation Management, 29(2), 245-256. http://dx.doi.org/10.1111/j.1540-5885.2011.00893.x

Powell, W. (1998). Learning from collaboration: knowledge and networks in the biotechnology and pharmaceutical industries. California Management Review, 40(3), 228. http://dx.doi.org/10.1016/B978-0-7506-7111-8.50005-6

Ray, C., \& Knight, M. (1991). Marketing innovation to mental health providers. Administration and Policy in Mental Health, 19(2), 92-102. http://dx.doi.org/10.1007/BF00706422

Romijn, H., \& Albaladejo, M. (2002). Determinants of innovation capability in small electronics and software firms in southeast England. Research Policy, 31(7), 1053-1067. http://dx.doi.org/10.1016/S0048-7333(01)00176-7

Shaw, B. (1994). User/supplier links and innovation. In: Dodgson, M., \& Rothwell, R. (Eds.). The Handbook of Industrial Innovation, Vermont, EUA. 
Shergill, G., \& Nargundkar, R. (2005). Market orientation, marketing innovation as performance drivers: extending the paradigm. Journal of Global Marketing, 19(1), 27-44. http://dx.doi.org/10.1300/J042v19n01_03

Van der Meer, H. (2007). Open innovation - the dutch treat: challenges in thinking in business models. Creativity and Innovation Management, 16(2), 192-202. http://dx.doi.org/10.1111/j.1467-8691.2007.00433.x

Von Hippel, E. (2005). Democratizing Innovation, Cambridge, MIT Press.

Von Hippel, E. (1988). Sources of Innovation, Oxford University Press, Oxford.

Wilhelm, M. (2011). Managing competition through horizontal supply chain relations: linking dyadic and networks levels of analysis. Journal of Operations Management, 29, 663-676. http://dx.doi.org/10.1016/j.jom.2011.03.003

Xie, C., Bagozzi, R., \& Troye, S. (2008). Trying to presume: toward a theory of consumers as co-creators of value. Journal of the Academy of Marketing Science, 36(1), 109-122. http://dx.doi.org/10.1007/s11747-007-0060-2 